\title{
Biodiversity of culturable heterotrophic bacteria in the Southern Adriatic Sea Italian coastal waters*
}

\author{
LOREDANA STABILI and ROSA ANNA CAVALLO \\ Istituto Ambiente Marino Costiero Sezione di Taranto, Talassografico “A. Cerruti”, CNR, Taranto, Italy. \\ E-mail: stabili@istta.le.cnr.it
}

\begin{abstract}
SUMMARY: The qualitative and quantitative composition of culturable heterotrophic bacteria in water samples from the Southern Adriatic Sea of Italy was examined. Water samples were collected monthly, for a year, at 16 stations along the coast line between Brindisi and Santa Maria di Leuca. The results obtained described the heterotrophic bacterial community over an annual cycle. Mean values of bacterial densities were $5.3 \times 10^{4} \mathrm{CFUml}^{-1}$ in Brindisi, $5.8 \times 10^{4} \mathrm{CFUml}^{-1}$ in S. Cataldo, $4.3 \times 10^{4} \mathrm{CFUml}^{-1}$ in Otranto and $6.7 \times 10^{4} \mathrm{CFUml}^{-1}$ in S. M. di Leuca. The differences in bacterial densities between the sites considered were estimated. The hydrodynamic circulation, the trophism and the geographical position of the examined sites contribute to justify the different bacterial density trends. The bacterial community consisted mainly of the genera Aeromonas, Pseudomonas, Photobacterium and Flavobacterium. The Enterobacteriaceae represented a considerable fraction of the bacterial community in the Southern Adriatic Sea. Bacilli were predominant among the Gram positive bacteria. The enzymatic versatility of the observed genera suggest their importance in organic matter turnover of this oligotrophic ecosystem.
\end{abstract}

Key words: culturable heterotrophic bacteria, Southern Adriatic Sea, biodiversity, abiotic parameters.

RESUMEN: BIODIVERSIDAD DE BACTERIAS HETERÓTROFAS CULTIVABLES EN LAS AGUAS COSTERAS ITALIANAS DEL MAR ADRIÁTICO MERIDIONAL. - Se examinó la composición cualitativa y cuantitativa de las bacterias heterótrofas cultivables en muestras de agua procedentes de aguas costeras italianas del mar Adriático meridional. Dichas muestras se recolectaron mensualmente, durante un año, en 16 estaciones a lo largo de la costa entre Brindisi y Santa Maria di Leuca. Los resultados obtenidos describen la comunidad bacteriana heterótrofa a lo largo de un ciclo anual. Los valores medios de las densidades bacterianas fueron $5.3 \times 10^{4} \mathrm{CFUml}^{-1}$ en Brindisi, $5.8 \times 10^{4} \mathrm{CFUml}^{-1} \mathrm{en} \mathrm{S}$. Cataldo, $4.3 \times 10^{4} \mathrm{CFUml}^{-1}$ en Otranto y $6.7 \times 10^{4}$ $\mathrm{CFUml}^{-1}$ en S. M. di Leuca. Se estimaron las diferencias en densidad bacteriana entre las distintas localidades. La circulación hidrodinámica, el trofismo y la posición geográfica de las localidades estudiadas contribuyen a explicar las distintas tendencias en densidad bacteriana. La comunidad bacteriana estaba constituida principalmente por los géneros Aeromonas, Pseudomonas, Photobacterium y Flavobacterium. Las Enterobacteriáceas representaban una fracción considerable de la comunidad bacteriana del mar Adriático meridional. Los bacilos eran predominantes entre las bacterias Gram positivas. La versatilidad enzimática de los géneros observados sugiere su importancia en el ciclado de la materia orgánica en este ecosistema oligotrófico.

Palabras clave: bacterias heterótrofas cultivables, mar Adriático meridional, biodiversidad, parámetros abióticos.

\section{INTRODUCTION}

A large number of studies in the past two decades show that heterotrophic bacteria not only function as

*Received September 18, 2001. Accepted November 21, 2002. decomposers, but also channel dissolved organic substrates and inorganic nutrients into higher trophic levels through the microbial food web (Pomeroy, 1980; Azam et al., 1983; Azam, 1998) hence facilitating the cycling of bioelements. The paramount importance of microbial life for the cycling of mat- 
ter in the oceans makes finding the identity of the indigenous bacteria an obvious research goal. However, heterotrophic bacteria are usually clumped together into a "black box" in conceptual and mathematical models. This anonymity is unwarranted since different marine bacteria, grown under the same conditions, exhibit different ectohydrolytic enzyme profiles, suggesting that different bacteria degrade different fractions of organic matter in the sea (Fuhrman et al., 1993; Martinez et al., 1996). Furthermore, the knowledge of the microbial communities composition may give important information about the different seawater habitats since bacteria respond quickly to abiotic changes in their environment. In fact, the vertical distribution of physical and chemical parameters such as temperature, salinity, oxygen content, and organic matter concentration in the marine water column may be the basis for a pronounced stratification of the prominent microbial populations (Sieburth, 1967; Rheinheimer and Gocke, 1994; Ramsing et al., 1996). However, it has been recognized that bacterial populations may be considerably modified by interactions with biotic factors. The link between bacteria and their main grazers, heterotrophic nanoflagellates, is believed to have a controlling function on bacterial abundance, growth and community composition (Sanders et al., 1992; Jürgens and Gude, 1994). Thus, further insight into marine bacterial diversity would be desirable.

Traditionally the diversity of marine bacteria has been assessed through identification with phenotypic tests and nutritional taxonomic approaches from collections of isolates from plating on nutrient media and enrichment. The results of such studies (Fry, 1987) have shown a relatively small number of genera being found most frequently, and these common types belonged mostly to the $\gamma$-Proteobacteria, Cytophaga-Flexibacter-Bacterioides (CFB) and gram-positive groups. The view that marine isolates are not representative of the indigenous bacteria stems from the unexplained disagreement between plate counts and the bacteria counted by epifluorescence microscopy and it has become the current dogma that marine bacteria are unculturable (Kogure et al., 1979). This problem was overcome when bacterial marine diversity was first investigated by $16 \mathrm{~S}$ rDNA approaches (Giovannoni et al., 1990). Culture independent studies of this kind are now common and have found many bacteria that are only known from their $16 \mathrm{~S}$ rRNA gene sequence and that do not match cultured bac- teria. Several of these are common in marine samples (e.g. SAR 11, Giovannoni et al., 1990; JAP 504 , Rochelle et al., 1994). At the same time, data demonstrating the dominant occurrence of culturable bacteria in the sea have been reported. With Southern California Blight isolates, Rehnstam et al. (1993), using $16 \mathrm{~S}$ rRNA probes, showed that single species of culturable bacteria can dominate the community DNA. Also Fuhrman et al. (1994) have reported that two culturable marine isolates each accounted for up to $20 \%$ of the bacterial community. Recent studies using various hybridization protocols (Gonzáles and Moran, 1997; Pinhassi et al., 1997; Hagström et al., 2000) showed that bacteria able to form colonies on solid media occupy a considerably larger fraction of the marine bacterial community than the number of colony-forming units would suggest.

On the basis of the mentioned studies it was assessed that the major phylogenetic groups of Bacteria most commonly abundant in marine habitats are the CFB, $\alpha$-Proteobacteria and $\gamma$-Proteobacteria. These groups contain many aerobic or facultative heterotrophs that are relatively easy to culture (e.g. $>60 \%$ of Proteobacteria and $>40 \%$ of CFB are culturable; Hugenholtz et al., 1998). Thus, we focussed our study on culturable heterotrophic bacteria. Knowledge about culturable heterotrophic marine bacteria biodiversity in the Mediterranean Sea is still insufficient. Concerning the Adriatic Sea, Zaccone et al. (1998) furnished some information on the quantitative and qualitative composition of the culturable heterotrophic bacterial community of the Northern Adriatic Sea during two different seasons. However, the Southern Adriatic Sea along Italian coasts has not been thoroughly investigated. In this work the quantitative and qualitative composition of culturable heterotrophic bacteria in water samples from the Southern Adriatic Sea were examined over an annual cycle.

\section{MATERIALS AND METHODS}

\section{Study site and sampling}

The Southern Adriatic Sea extends from the Pelagosa sill (north) to the Otranto sill (south) which divides it from the Ionian Sea. This study was carried out from April 1996 to March 1997 in four transects of the Southern Adriatic Sea: Brindisi, S. Cataldo, Otranto and Santa Maria di Leuca 


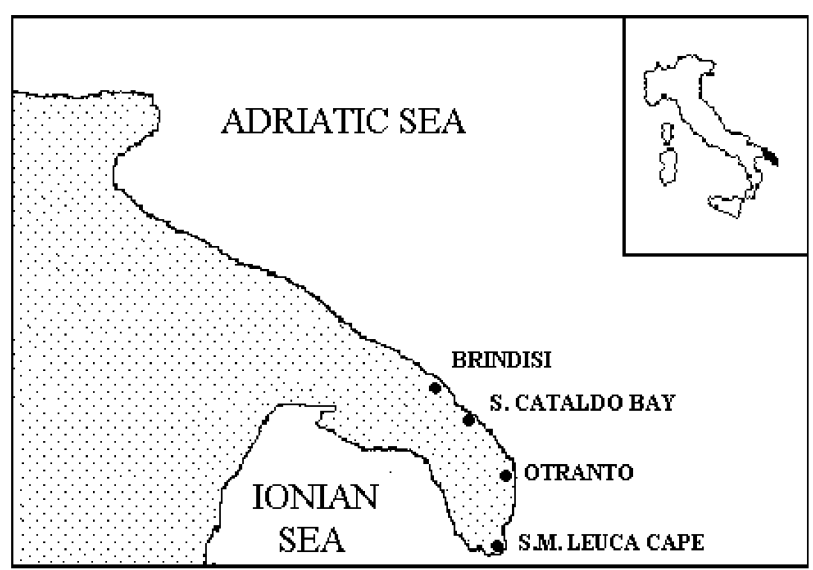

FIG. 1. - Map of the Southern Adriatic Sea of Italy showing the locations of the sampling sites.

(Fig.1). For each examined transect four sampling points, perpendicular to the shore, were fixed. They were referred to as stations 1 (located at 0.5 kilometers from the coastal line), $2(3 \mathrm{Km}), 3(5 \mathrm{Km})$ and $4(10 \mathrm{Km})$. Water samples were taken, once a month, at $0.5 \mathrm{~m}$ below the water surface and at 0.5 $\mathrm{m}$ above the bottom (between 5 and $50 \mathrm{~m}$ depth depending on the bathimetry of each site). Brindisi is an industrial city (about 100.000 inhabitants) with a touristic and commercial port, S. Cataldo is a small touristic village, Otranto and S. M. di Leuca are two small touristic towns (about 5.500 inhabitants each one).

In this coastal tract of the Southern Adriatic Sea Caroppo et al. (1999) observed annual averages of ammonia around $0.2 \mathrm{~g} \mathrm{~g}^{-1}$, nitrates mean values of $1.3 \mu \mathrm{g} \mathrm{l}^{-1}$, nitrites of $0.2 \mu \mathrm{g} \mathrm{l}^{-1}$ and phosphorus as orthophosphate from 0.01 to $0.1 \mu \mathrm{g} \mathrm{l}^{-1}$.

\section{Abiotic parameters}

Temperature, $\mathrm{pH}$, salinity and dissolved oxygen were measured in situ using a multiparametric sounding-line "Ocean Seaven 401" (Jolzonant, Italy).

\section{Bacteriological methods}

Water samples were collected with 5 L Niskin bottles. The sampling bottles were acid cleaned $(10 \% \mathrm{HCl})$ and rinsed with distilled water before use. Samples were transferred into sterile polycarbonate flasks and processed, for enumeration and isolation of bacteria, within $4 \mathrm{~h}$ of sampling. In the laboratory, the number of colony-forming units (CFU) was determined by plating $100 \mu \mathrm{l}$ of undilut- ed seawater and serial dilutions of each water sample in triplicates on Bacto Marine Agar 2216 (Difco). The plates were incubated at $22^{\circ} \mathrm{C}$ over 7 days. At the end of the incubating period all the colonies were counted through a x 10 magnifying glass. All colonies were isolated, subcultured and identified by several morphological, biochemical and cultural methods (Holt et al., 1994).The standardized API 20 System (Biomerieux SA, France) was used on the isolates to study the following biochemical characteristics: hydrolysis of gelatin, nitrate reductase, presence of B-galactosidase, carbohydrate utilization: saccharose, arabinose, mannitol, fructose, glucose, maltose, starch, rhamnose, galactose, mannose, sorbitol, glycerol, urease, indole, $\mathrm{H}_{2} \mathrm{~S}$ and acetoine production, and citrate utilization. To adjust the salinity to a value more representative of sea water, a $3 \% \mathrm{NaCl}$ solution was added to the suspension medium. The galleries were incubated for 2 days at room temperature.

\section{Statistical analysis}

The bacterial concentrations were log transformed and statistical analysis was performed by using the STATSOFT STATISTICA v. 6.0 (Statsoft, 2001).

\section{RESULTS}

\section{Abiotic parameters}

The main physico-chemical characteristics of the sampling points such as temperature, salinity, $\mathrm{pH}$, and dissolved oxygen are reported in Figure 2. The lowest seasonal temperatures were reached in March both at the surface and the bottom. Summer warming up started in May with temperatures never above $19^{\circ} \mathrm{C}$ and the highest temperature values were observed in August at the surface, when the greatest thermal excursion between the surface and water at a depth of $50 \mathrm{~m}$ was observed. At the bottom the highest temperatures were recorded in Brindisi in August, in S. Cataldo in September, in Otranto and S. M. di Leuca in October. Salinity showed lowest values in winter with surface values between 36.9 and $37.7 \%$. The highest value of $38.6 \%$ was reached in S. Cataldo at the surface in November. The $\mathrm{pH}$ values oscillated from 7.9 to 8.41 . Water samples from the different stations showed an oxygen mean percentage saturation of 109.7. 
(Surface)
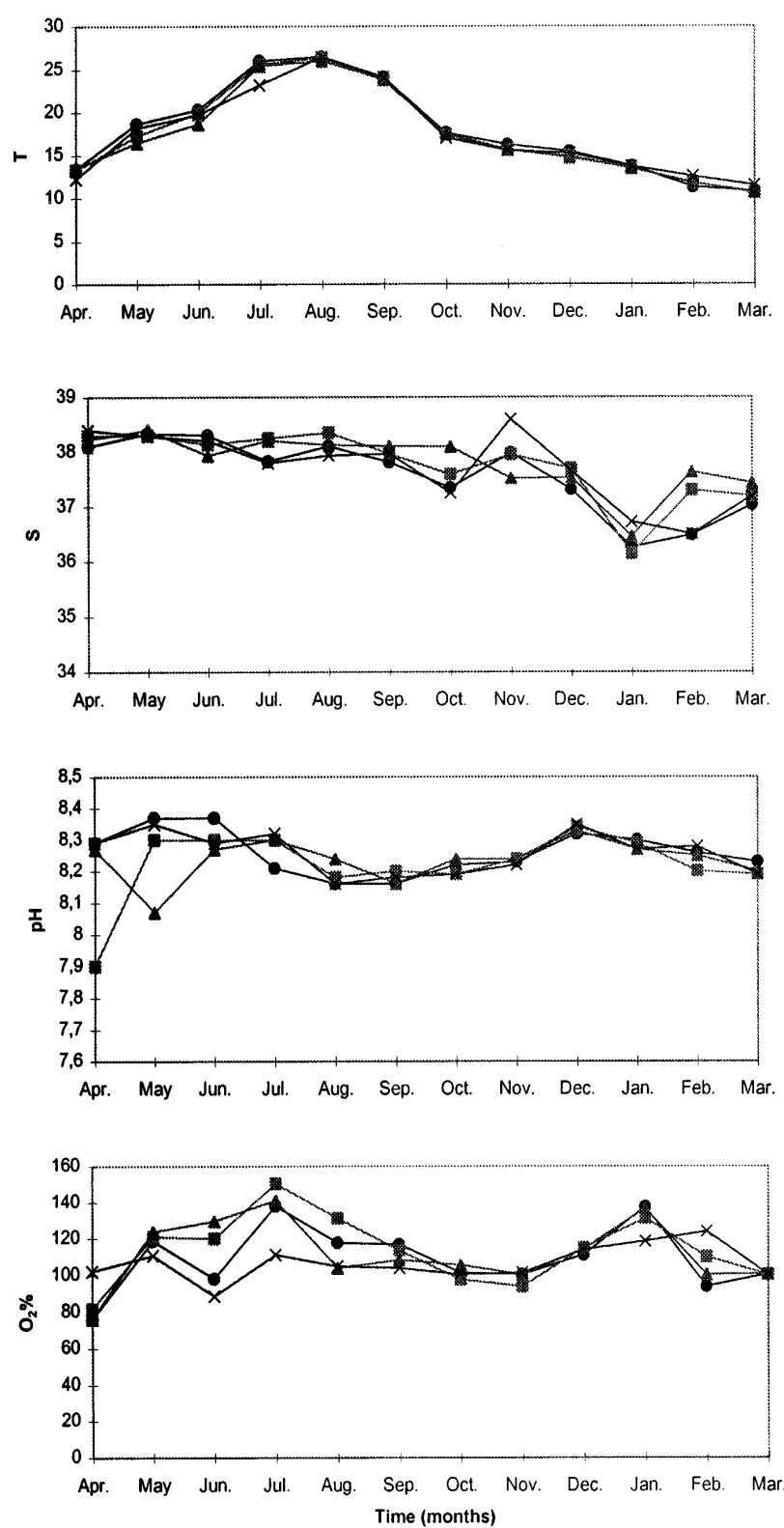

$\rightarrow-$ Brindisi $\quad-$ - Otranto $\quad$ S. M. di Leuca $\quad$ - - S. Cataldo
(Bottom)
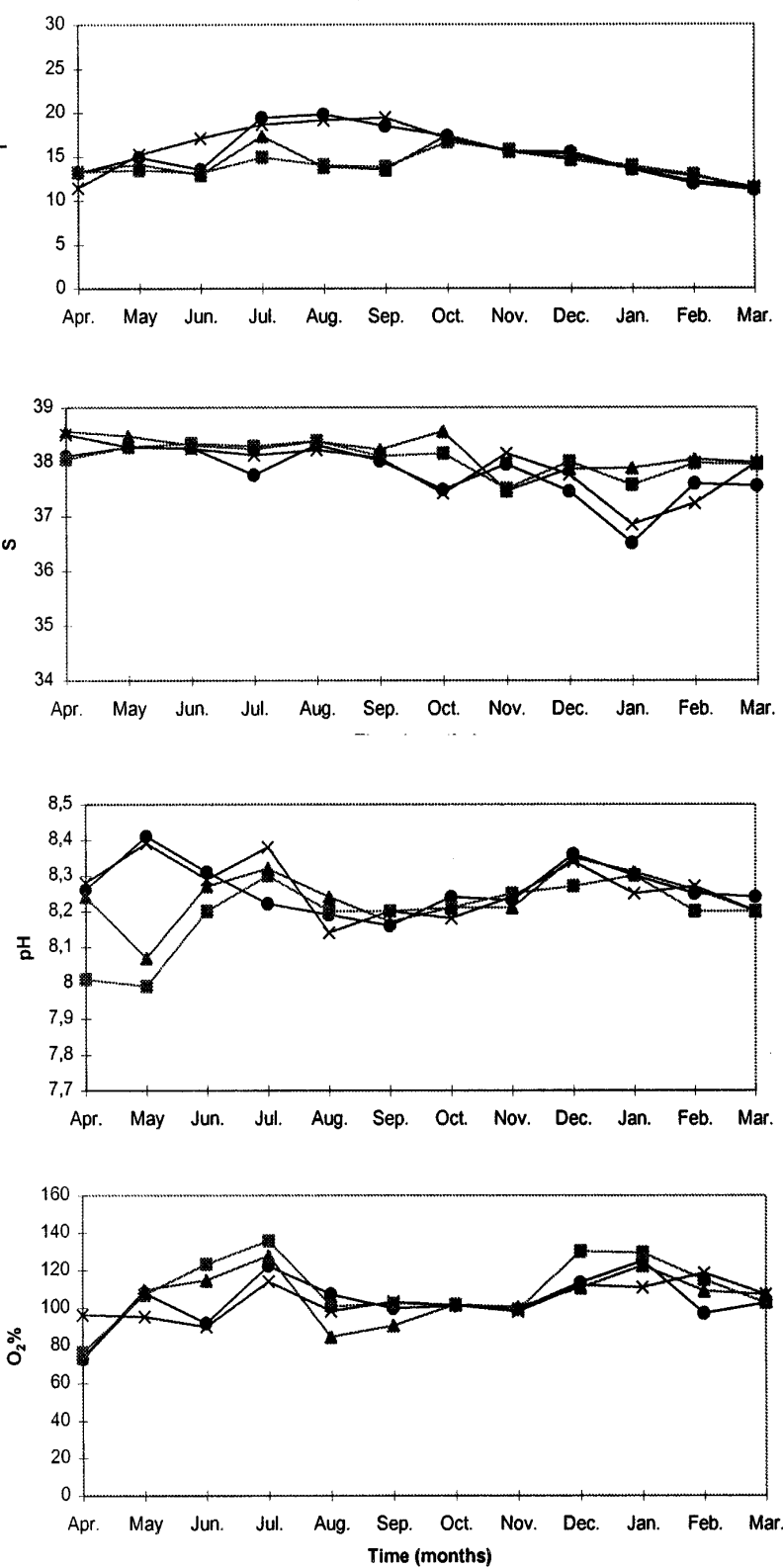

$\rightarrow$ Brindisi $\quad \rightarrow-$ Otranto $\rightarrow$ S. M. di Leuca $\quad *$ S. Cataldo

FIG. 2. - Yearly values of: Temperature $\left(\mathrm{T},{ }^{\circ} \mathrm{C}\right)$, Salinity $(\mathrm{S}, \% o), \mathrm{pH}$, dissolved oxygen $\left(\mathrm{O}_{2} \%\right)$, measured at the various sampling sites.

\section{Heterotrophic bacterial counts}

Culturable heterotrophic bacterial densities were usually higher at the bottom than at the surface in all the stations examined. In Brindisi the mean bacterial densities were $4.0 \times 10^{4} \mathrm{CFU} \mathrm{ml}^{-1}$ in the surface sample and $6.6 \times 10^{4} \mathrm{CFU} \mathrm{ml}^{-1}$ in the deep sample, in S. Cataldo $4.6 \times 10^{4}$ and $7.0 \times 10^{4} \mathrm{CFU}$ $\mathrm{ml}^{-1}$, in S. M. di Leuca $6.4 \times 10^{4}$ and $7.0 \times 10^{4} \mathrm{CFU}$ $\mathrm{ml}^{-1}$. Only at Otranto were the mean values of heterotrophic bacterial counts comparable in the sur- face and depth samples $\left(4.3 \times 10^{4} \mathrm{CFU} \mathrm{ml} \mathrm{m}^{-1}\right)$. The seasonal changes in culturable heterotrophic bacterial densities are shown in Figures 3a, b, c, and d. In Brindisi (Fig. 3a) the trend of the bacterial abundances showed several peaks and the lowest values both at the surface and the bottom were observed in October. No relationship between the bacterial abundance and the temperature was observed $(\mathrm{R}=$ 0.094, $\mathrm{p}<0.01, \mathrm{n}=96$ ). In S. Cataldo (Fig. 3b) the bacterial counts displayed higher values during the spring-summer period either at the surface or at the 
(Brindisi)

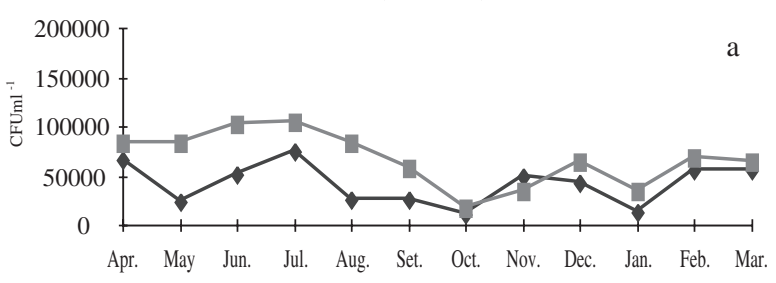

(Otranto)

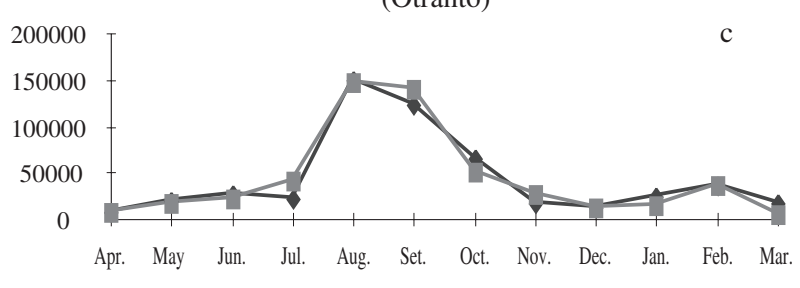

$\neg$ surface $\rightarrow-$ bottom

(S. Cataldo)

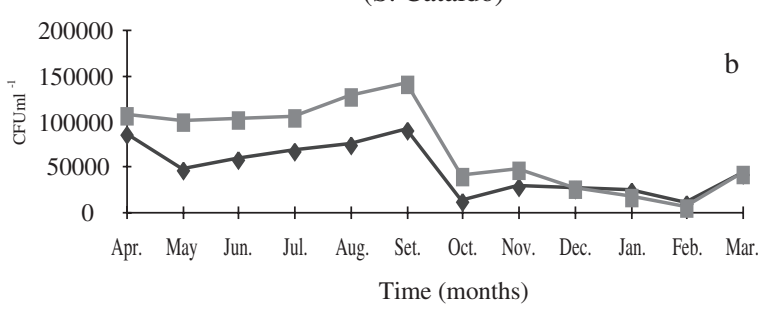

(S. M. di Leuca)

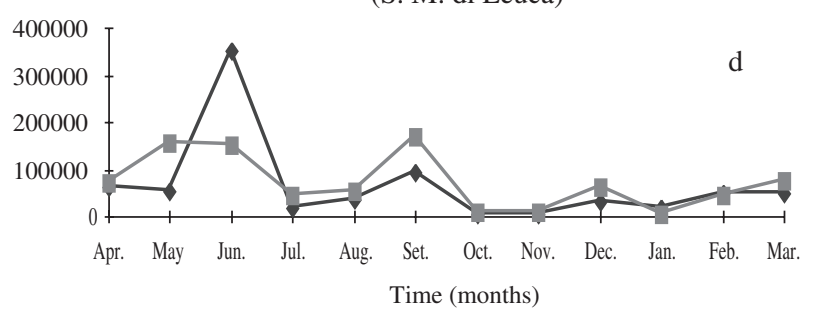

FIG. 3. - Culturable heterotrophic bacterial abundance over an annual cycle in Brindisi (a), S. Cataldo (b), Otranto (c) and Santa Maria di Leuca (d), at the surface and bottom levels.

bottom, whereas the lowest densities were observed in October and February. At this site a significantly positive relationship between the bacterial abundance and the temperature $(\mathrm{R}=0.639, \mathrm{p}<0.01, \mathrm{n}=$ 96) was found. In Otranto (Fig. 3c) the highest concentrations of the culturable heterotrophic bacteria were monitored in the August-September period both at the surface and the bottom. Also, in this site as well as in S. Cataldo, a significantly positive relationship between the bacterial density and the temperature was observed $(\mathrm{R}=0.545, \mathrm{p}<0.01, \mathrm{n}=$ 96). In S. M. di Leuca (Fig. 3d) the pattern of the microbial abundances was more diversified compared with those of the other sites: several peaks and declines occurred. No relationship was observed between the bacterial abundance and the temperature $(\mathrm{R}=0.009, \mathrm{p}<0.01, \mathrm{n}=96)$.

\section{Bacterial biodiversity}

It was possible to identify up to the genus level about $86 \%$ of the isolates grown on Marine agar. In all the sampling sites (Figs. 4, 5, 6, 7, 8) the Gramnegative bacteria prevailed over the Gram-positive ones. The genus Aeromonas dominated in all the four transects examined either at the surface or at the bottom with a mean percentage of isolation at the surface of 23, 13, 19.4 and $13.6 \%$ in Brindisi, S. Cataldo, Otranto and S. M. di Leuca respectively, and 15.5, $15,18.2$ and $15.2 \%$ at the bottom. Apart from

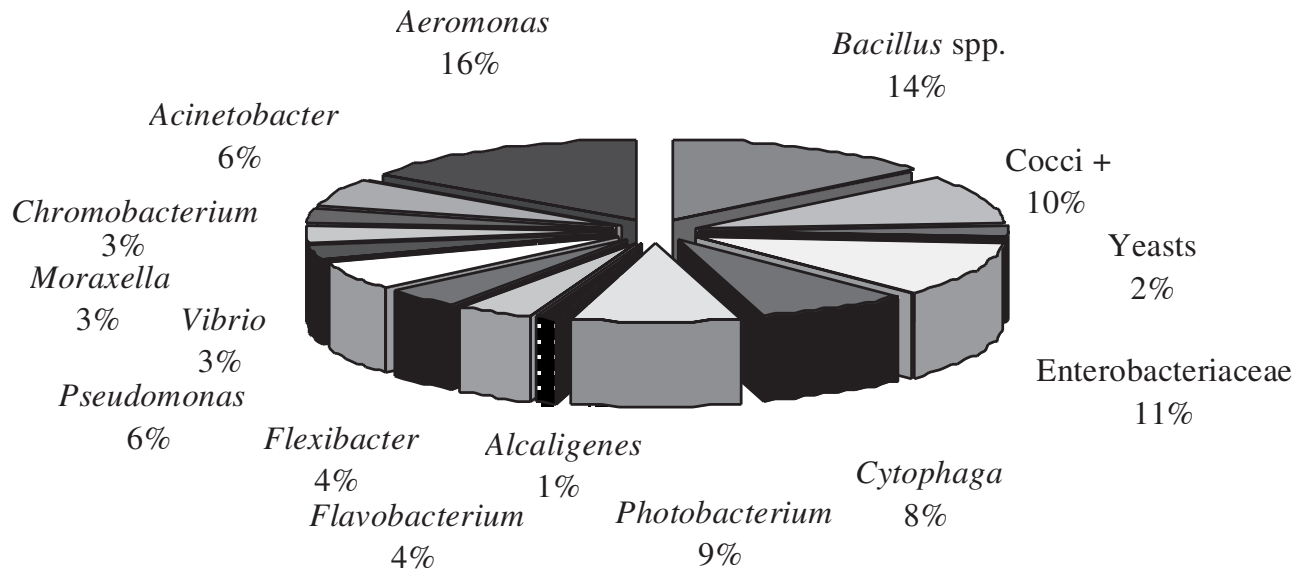

FIG. 4. - Qualitative analysis of culturable heterotrophic bacterial community over an annual cycle in the Southern Adriatic Sea. 

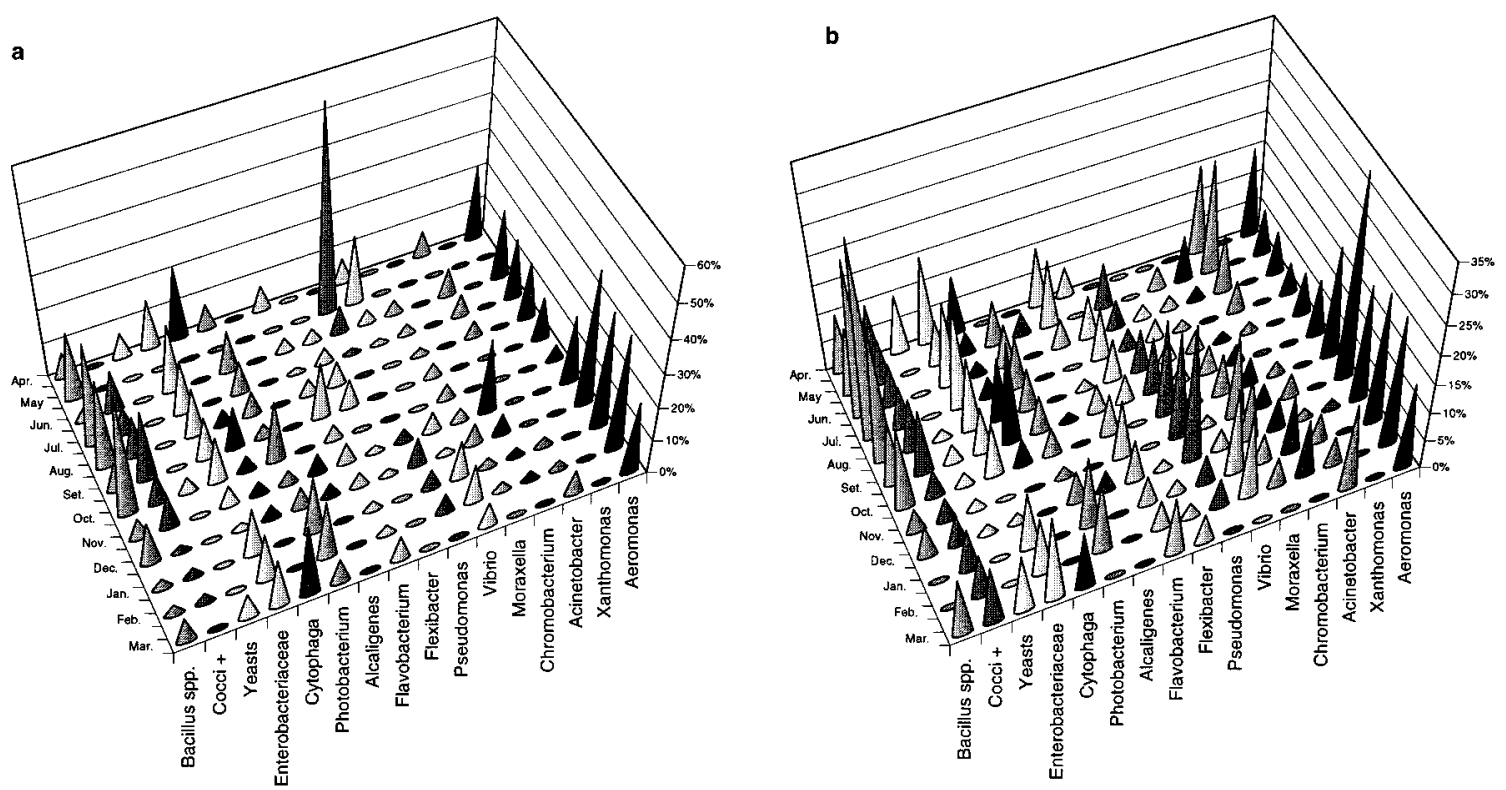

FIG. 5. - Annual trend of culturable heterotrophic bacterial diversity in Brindisi at surface (a) and bottom (b).
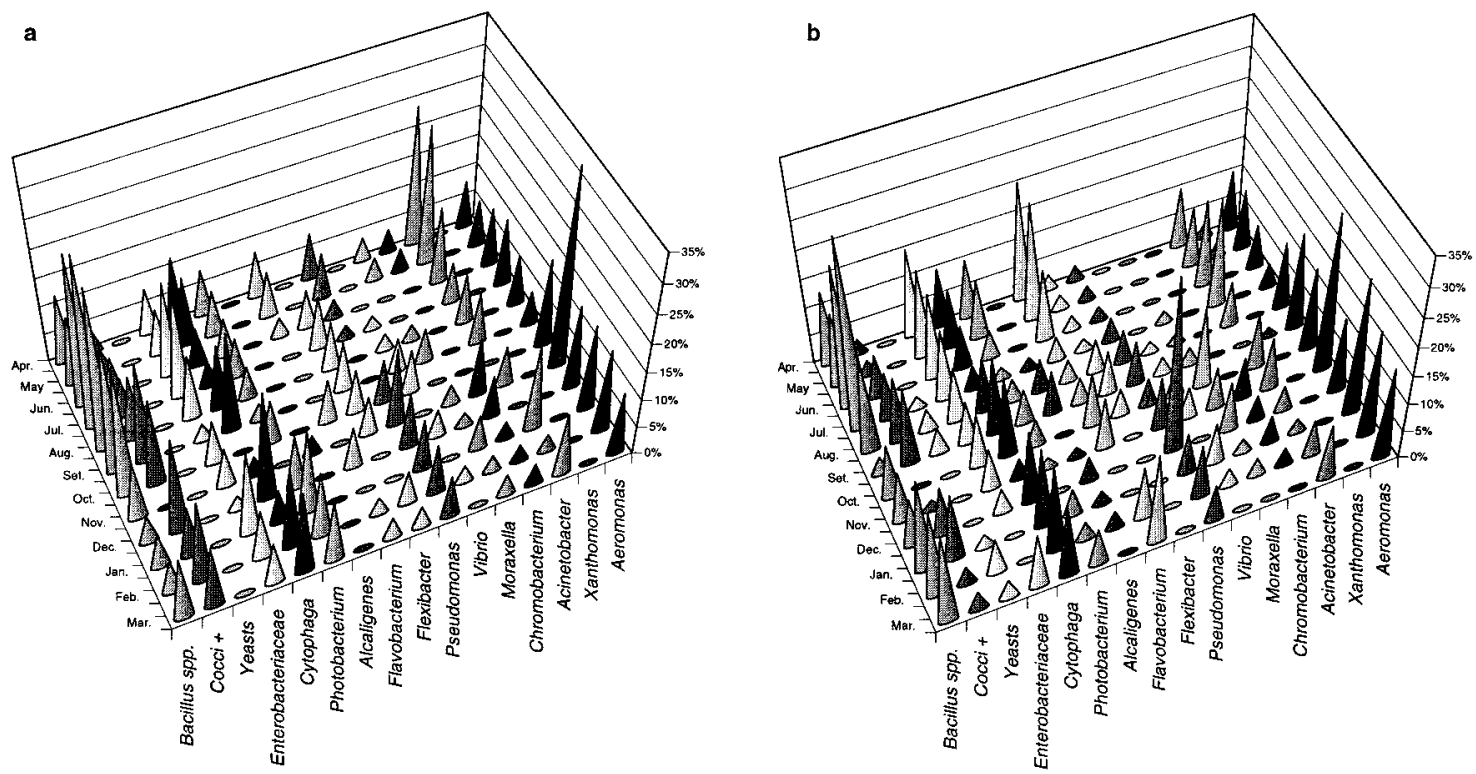

FIG. 6. - Annual trend of culturable heterotrophic bacterial diversity in S. Cataldo at surface (a) and bottom (b).

Aeromonas, the culturable bacterial community of the Southern Adriatic Sea consisted mainly of the genera Pseudomonas, Photobacterium, Cytophaga, Acinetobacter and Flavobacterium (Fig. 4). The family Enterobacteriaceae represented a considerable fraction of the bacterial community too. In Brindisi in fact the mean isolation percentage was $11.9 \%$ at the surface and $9.7 \%$ at the bottom. In S. Cataldo the Enterobacteriaceae were found throughout the year except in January and February at the bottom with a mean isolation percentage of about $9.5 \%$. In Otranto this family showed a mean isolation percentage of $13.4 \%$ and in S. M. di Leuca of $10.4 \%$. Results con- cerning the main culturable bacterial genera isolated in the four transects of the Southern Adriatic Sea are summarized in Table 1. Pseudomonas was present with a mean value of $8 \%$ in Brindisi, of $6.6 \%$ in $\mathrm{S}$. Cataldo and $7.6 \%$ in S. M. di Leuca. In Otranto Pseudomonas was more abundant at the bottom $(10 \%)$ than at the surface (4\%). Photobacterium was isolated with a mean isolation percentage of $7.5 \%$ in Brindisi, $6.5 \%$ in S. Cataldo, $8.9 \%$ in Otranto and 9.9\% in S. M. di Leuca. In this last transect the presence of Photobacterium was comparable to Aeromonas at the surface (mean isolation percentage of 13.6\%). Cytophaga, Moraxella, Acinetobacter, 

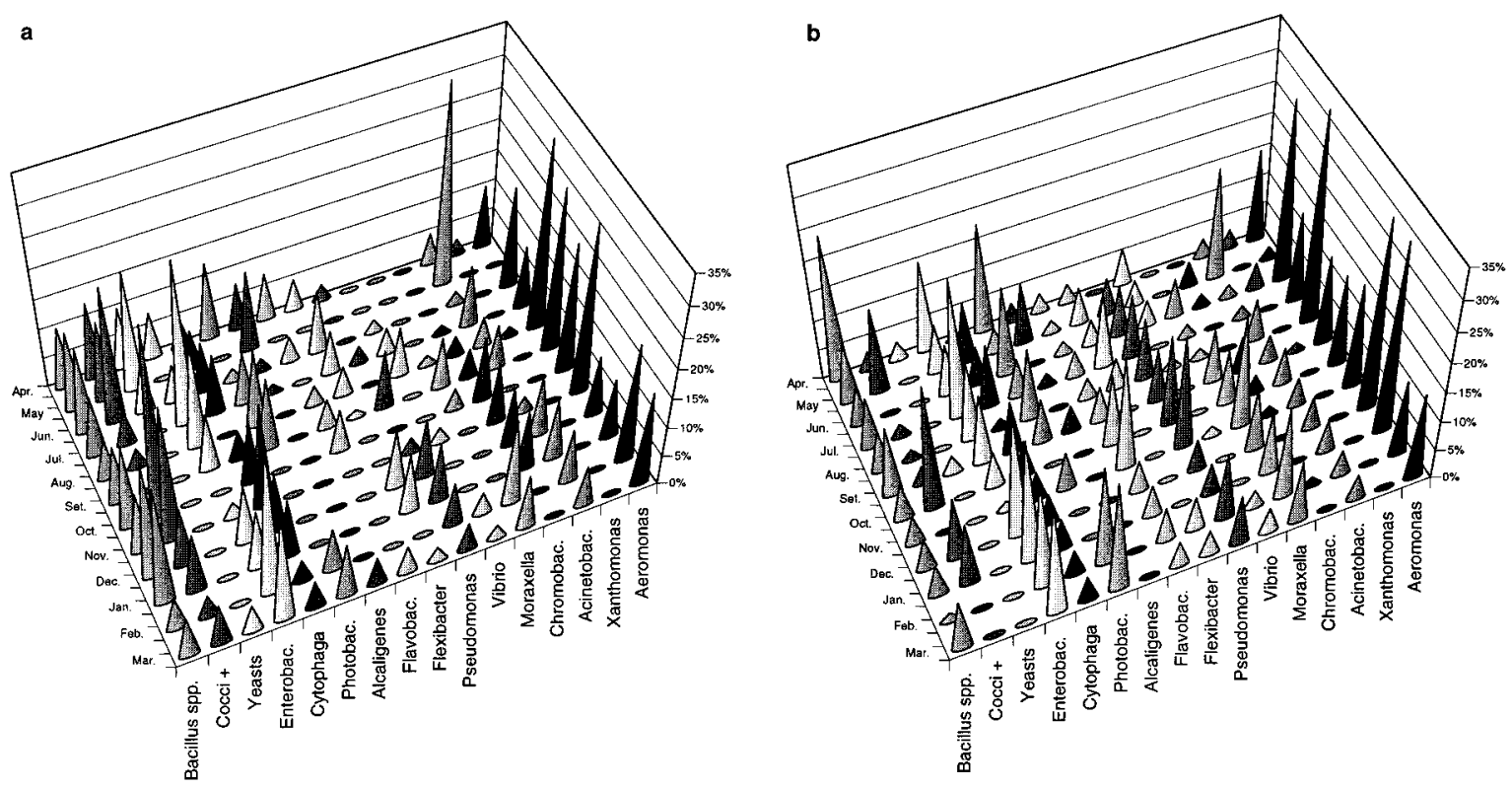

FIG. 7. - Annual trend of culturable heterotrophic bacterial diversity in Otranto at surface (a) and bottom (b).
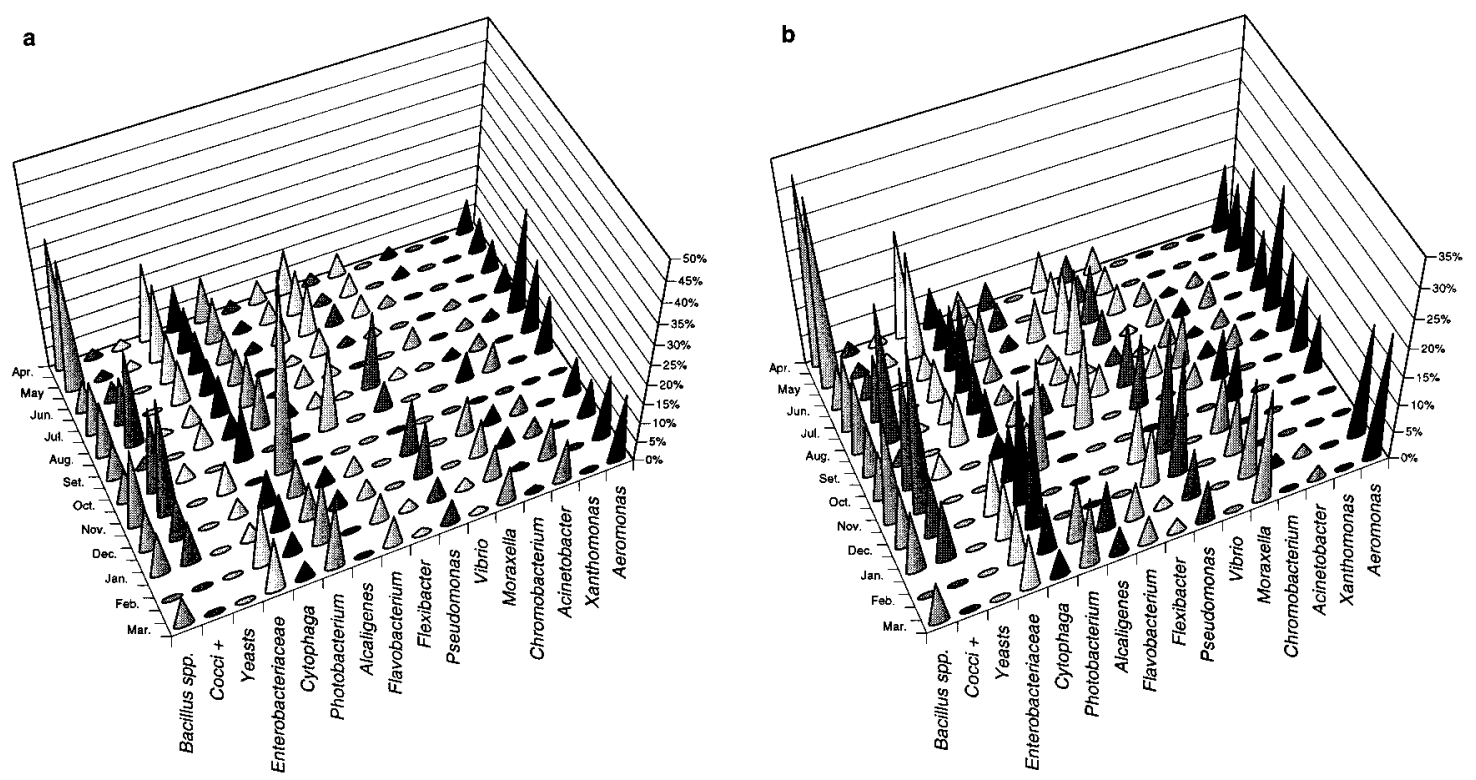

FIG. 8. - Annual trend of culturable heterotrophic bacterial diversity in Santa Maria di Leuca at surface (a) and bottom (b).

and Flavobacterium were identified with a total isolation percentage less than $6.5 \%$ in Brindisi and Otranto whereas in S. Cataldo the presence of Cytophaga $(10.6 \%)$ and Acinetobacter $(9.1 \%)$ was remarkable. Also in S. M. di Leuca the occurrence of Cytophaga (8.9\%) was conspicuous. Vibrio was evidenced with a low mean isolation percentage and was more abundant in the January-February period in Brindisi both at the surface and the bottom. In S. Cataldo the highest isolation percentage occurred in October at the surface (8\%) and in January at the bottom $(7 \%)$. In Otranto the mean isolation percentage of Vibrio was 2\% and the highest concentration was found at the surface in August (8\%). In S. M. di Leuca Vibrio showed a mean isolation percentage of $2.6 \%$ and was absent during the October-January period. In all the transects considered, among the Gram-positive bacteria, bacilli were predominant. Yeasts were occasionally isolated. From the analysis of the seasonal succession of the heterotrophic bacterial biodiversity it is evident that in Brindisi bacterial diversity was strongly reduced in May at the surface. During the other months no substantial differences in the bacterial community composition were observed. In S. Cataldo the bacterial community diversity was uniform throughout the year both at the surface and 
TABLE 1. - Mean isolation percentages of the main bacterial genera present in the four transects of the Southern Adriatic Sea.

\begin{tabular}{|c|c|c|c|c|c|c|c|c|c|c|}
\hline & & nterobacteriaceae & Cytophaga & Photobacterium & Flavobacterium & Pseudomonas & Vibrio & Moraxella & Acinetobacter & Aeromonas \\
\hline \multirow[t]{4}{*}{ Apr. } & Brindisi & 15 & 16 & 4 & 9 & 0 & 4 & 0 & 11 & 18 \\
\hline & S. Cataldo & 12 & 11 & 9 & 14 & 5 & 0 & 2 & 17 & 9 \\
\hline & Otranto & 11 & 3 & 16 & 5 & 1 & 3 & 0 & 4 & 13 \\
\hline & S. M. di Leuca & 19 & 9 & 8 & 3 & 4 & 5 & 0 & 0 & 10 \\
\hline \multirow[t]{4}{*}{ May } & Brindisi & 0 & 0 & 0 & 0 & 60 & 20 & 0 & 0 & 0 \\
\hline & S. Cataldo & 8 & 12 & 8 & 8 & 8 & 0 & 4 & 24 & 8 \\
\hline & Otranto & 4 & 8 & 2 & 1 & 3 & 2 & 0 & 26 & 1 \\
\hline & S. M. di Leuca & 19 & 9 & 8 & 3 & 4 & 5 & 0 & 0 & 10 \\
\hline \multirow[t]{4}{*}{ Jun. } & Brindisi & 17 & 1 & 10 & 4 & 6 & 3 & 3 & 9 & 14 \\
\hline & S. Cataldo & 16 & 7 & 6 & 8 & 3 & 0 & 0 & 14 & 9 \\
\hline & Otranto & 7 & 7 & 8 & 3 & 4 & 3 & 3 & 2 & 23 \\
\hline & S. M. di Leuca & 9 & 11 & 8 & 8 & 8 & 5 & 3 & 1 & 13 \\
\hline \multirow[t]{4}{*}{ Jul. } & Brindisi & 17 & 2 & 9 & 1 & 3 & 3 & 2 & 6 & 11 \\
\hline & S. Cataldo & 16 & 4 & 5 & 2 & 3 & 1 & 1 & 13 & 8 \\
\hline & Otranto & 25 & 10 & 8 & 2 & 7 & 2 & 1 & 6 & 13 \\
\hline & S. M. di Leuca & 9 & 13 & 7 & 3 & 4 & 2 & 2 & 3 & 8 \\
\hline \multirow[t]{4}{*}{ Aug. } & Brindisi & 14 & 8 & 7 & 3 & 4 & 2 & 3 & 3 & 12 \\
\hline & S. Cataldo & 11 & 11 & 5 & 2 & 3 & 2 & 2 & 8 & 10 \\
\hline & Otranto & 16 & 1 & 13 & 3 & 5 & 5 & 2 & 6 & 33 \\
\hline & S. M. di Leuca & 6 & 10 & 8 & 5 & 2 & 1 & 5 & 3 & 24 \\
\hline \multirow[t]{4}{*}{ Set. } & Brindisi & 10 & 15 & 5 & 11 & 5 & 2 & 5 & 0 & 11 \\
\hline & S. Cataldo & 5 & 16 & 5 & 2 & 4 & 4 & 4 & 4 & 11 \\
\hline & Otranto & 11 & 7 & 10 & 5 & 9 & 0 & 9 & 6 & 21 \\
\hline & S. M. di Leuca & 8 & 7 & 9 & 5 & 15 & 4 & 5 & 4 & 16 \\
\hline \multirow[t]{4}{*}{ Oct. } & Brindisi & 12 & 5 & 11 & 6 & 8 & 1 & 6 & 1 & 12 \\
\hline & S. Cataldo & 9 & 7 & 6 & 9 & 6 & 6 & 7 & 5 & 15 \\
\hline & Otranto & 3 & 8 & 0 & 10 & 8 & 0 & 6 & 3 & 18 \\
\hline & S. M. di Leuca & 0 & 9 & 2 & 19 & 10 & 0 & 2 & 4 & 14 \\
\hline \multirow[t]{4}{*}{ Nov. } & Brindisi & 3 & 2 & 3 & 8 & 11 & 4 & 9 & 2 & 27 \\
\hline & S. Cataldo & 7 & 4 & 1 & 5 & 11 & 3 & 5 & 8 & 31 \\
\hline & Otranto & 2 & 11 & 3 & 10 & 11 & 2 & 10 & 4 & 23 \\
\hline & S. M. di Leuca & 4 & 5 & 35 & 0 & 0 & 0 & 0 & 0 & 5 \\
\hline \multirow[t]{4}{*}{ Dec. } & Brindisi & 2 & 2 & 6 & 6 & 16 & 3 & 9 & 1 & 30 \\
\hline & S. Cataldo & 3 & 16 & 5 & 4 & 20 & 2 & 6 & 2 & 14 \\
\hline & Otranto & 16 & 8 & 0 & 3 & 8 & 0 & 5 & 8 & 21 \\
\hline & S. M. di Leuca & 8 & 16 & 5 & 2 & 18 & 0 & 10 & 2 & 5 \\
\hline \multirow[t]{4}{*}{ Jan. } & Brindisi & 12 & 0 & 15 & 4 & 5 & 13 & 4 & 4 & 28 \\
\hline & S. Cataldo & 8 & 10 & 10 & 0 & 8 & 4 & 4 & 9 & 19 \\
\hline & Otranto & 16 & 8 & 0 & 3 & 8 & 0 & 5 & 8 & 21 \\
\hline & S. M. di Leuca & 8 & 16 & 5 & 2 & 18 & 0 & 10 & 2 & 5 \\
\hline \multirow[t]{4}{*}{ Feb. } & Brindisi & 12 & 0 & 15 & 4 & 5 & 13 & 4 & 4 & 28 \\
\hline & S. Cataldo & 4 & 15 & 7 & 6 & 9 & 3 & 3 & 5 & 17 \\
\hline & Otranto & 22 & 4 & 12 & 3 & 9 & 3 & 15 & 7 & 16 \\
\hline & S. M. di Leuca & 14 & 7 & 14 & 7 & 7 & 1 & 13 & 6 & 18 \\
\hline \multirow[t]{4}{*}{ Mar. } & Brindisi & 15 & 16 & 4 & 9 & 0 & 4 & 0 & 11 & 18 \\
\hline & S. Cataldo & 9 & 14 & 9 & 10 & 7 & 0 & 2 & 10 & 14 \\
\hline & Otranto & 18 & 4 & 14 & 4 & 6 & 3 & 10 & 5 & 15 \\
\hline & S. M. di Leuca & 12 & 5 & 15 & 6 & 7 & 1 & 15 & 7 & 20 \\
\hline
\end{tabular}

at the bottom. In Otranto the bacterial diversity was unchanged throughout the year at the bottom whereas at the surface it decreased in May and increased in March. In S. M. di Leuca the bacterial community diversity declined drastically in November both at the surface and the bottom.

\section{DISCUSSION}

The present investigation contributes to the knowledge of culturable heterotrophic bacteria in the waters of the Southern Adriatic Sea along Italian Apulian coasts by the quantitative and qualitative description of the variations over an annual cycle. The Southern Adriatic Sea is characterized by high hydrodynamic circulation related to rapid water exchange due to the overlapping of water masses having different thermoaline features and flowing in both directions, from the Northern Adriatic Sea and from the Ionian Sea in the Otranto Strait (Russo and Artegiani, 1996). The outgoing flow towards the Ionian Sea is made up of Adriatic Surface Waters (ASW) and overlapping Adriatic Deep Waters (ADW) present all along the Italian west coast. Inlet flow, instead, is composed of Ionian Surface Waters (ISW) and Levantine Intermediate Waters (LIW) found in the basin mainly on the Greek and Alban- 
ian eastern coasts (Orlic et al., 1992). In summer, the gap between these two water types is the greatest, which gives rise to a very strong out-flowing current from the Adriatic mainly in the Otranto Channel (Franco et al., 1982). In winter the strongest current comes in along the eastern coast. In spring and autumn the strength of the incoming current equals that of the outgoing one. The overall circulation in the lower Adriatic Sea as well as the resulting trophic resources availability seem to affect the bacterial abundances in those transects of the Southern Adriatic Sea not exposed to allochthonous inputs (S. Cataldo, Otranto and S. M di Leuca). Particularly, in $\mathrm{S}$. Cataldo and Otranto the minimum values in temperature coincided with the minimum values in bacterial densities and a positive relationship between the water temperature and the culturable heterotrophic bacterial counts were observed. Thus, the bacterial densities seemed limited by temperature during non-summer seasons. Nevertheless temperature is not the only causation in reducing bacterial densities in the winter period in these two transects of the Southern Adriatic Sea. Pomeroy and Wiebe (2001) provided indirect evidence that the temperature and substrate concentration are potential limiting factors that interact in temperate ocean surface waters and estuarine waters. Limiting resources for bacteria are, typically, labile carbon substrates as well as inorganic and organic $\mathrm{N}$ and $\mathrm{P}$ (Pace and Funke, 1991). Bacteria are strong competitors with phytoplankton for inorganic nutrients (Jürgens and Gude, 1990; Suttle et al., 1990). In such a competition, in winter, phytoplankton prevailed; in fact a vernal phytoplanktonic bloom was evidenced in the Southern Adriatic Sea (Caroppo et al., 1999).

In summer, the temperature was favourable to the bacterial growth as well as the substrate supply increase. In this season the effects of the hydrological features determined the very low dissolved inorganic nutrient concentration which leads to low phytoplankton biomass (Caroppo et al., 1999; Gacic et al., 1996). The lack of nutrients could favour a trophic web consisting of small cells as producers, as pico- and nanoplankton are more efficient in the utilization of the resources in oligotrophic systems (Thingstad and Sakshaug, 1990). In these conditions, regenerative dissolved organic phosphorus (DOP) and nitrogen (DON) may represent an important source of nutrients available for the culturable bacteria. In fact, the presence of DOP has been documented in this area typically in this period of the year (Civitarese et al., 1998).
S. M. di Leuca, because of its geographical position, at the extreme point of the Apulia, is influenced by both the incoming ASW from the Northern Adriatic Sea and the incoming LIW from the Ionian Sea both furnishing resources. The ASW, coming from a basin heavily supplied by rivers, features low salinity and high levels of dissolved nutrients, as well as high suspended matter concentration (Fonda Umani et al., 1992; Franco and Michelato, 1992). The LIW is relatively rich in nutrients (Civitarese et al., 1998). Thus, in this site the continuous loading of nutrients stimulates the bacterial growth, masking the effect of the other environmental factors, including temperature. This situation could explain the absence of a significant relationship between the culturable bacteria density and the temperature in S. M. di Leuca.

The situation recorded in Brindisi was quite different. Brindisi is an industrial city with a touristic and commercial port which is set in a bay receiving considerable amounts of allochthonous inputs (industrial and agricultural wastes). These furnish trophic resources throughout the year and stimulate bacterial growth independently from the environmental factors. This situation could explain the scarce modifications in the bacterial abundances observed throughout the sampling year at this transect and the absence of a significative relationship between the bacterial density and the temperature.

In recent years, preserving the world's biodiversity has become a priority in environmental studies. Because of bacterial importance in the marine environment it is vital to understand the full extent of bacterial diversity and the roles of the most abundant species. The use of both cultivation-based and cultivation-independent approaches has provided new perspectives on the nature of bacterioplankton communities in the sea over the past decade (Giovannoni et al., 1990; Suzuki et al., 1997). Major groups that contain cultivable members include the gamma proteobacteria (i.e. Vibrio spp., Pseudoalteromonas spp. and Pseudomonas spp.), the Flexibacter, Bacteroides and Cytophaga phylum (i.e. Cytophaga spp. and Flavobacterium spp.), the Cyanobacteria (Synechococcus spp. and Prochlorococcus spp.) and the $\alpha$-proteobacteria. In our study some genera representative of these groups were isolated. Aeromonas spp. prevailed among the Gram-negative bacteria identified. Aeromonads are among the most abundant bacteria found in aquatic environments. They also belong to the flora of fish, amphibia and other marine organisms (Shotts et al., 1972; Kueh and 
Chan, 1985). Bacterial infections caused by motile members of the genus Aeromonas are among the most common and troublesome diseases in fish. These Aeromonads are facultative, which means they are capable of utilizing nutrients present in water and surviving for long periods in the absence of host fish (Camus et al., 1998). Enterobacteriaceae were quite abundant during the whole sampling period. A similar pattern was seen for Cytophaga, Pseudomonas and Photobacterium. The enzymatic versatility of these genera is well known and has been suggested as an explanation of their importance in particle turnover (De Long et al., 1993). As naturally occurring bacteria, Cytophaga spp. are capable of the biodegradation of natural polymers such as cellulase, pectin, keratin, agar and chitin as well as the degradation and purification of organic compounds such as phenol, o-cresol and orcinol. The isolation of Cytophaga in our work is in good agreement with other studies that report frequent isolation of this genus in marine samples. Members of the Cytophaga-Flavobacterium group usually formed a large bacterial group in marine water. The relative abundance ranged from $2 \%$ in the Baltic Sea to $72 \%$ in the Antarctic Ocean (Glöckner et al., 1999). Pseudomonas represents a fraction of the total microbial population characterized by high metabolic versatility: this genus plays an important role in the mineralization of organic matter and in nitrogen cycling and it is known for its capacity to degrade a considerable quantity of synthetic organic compounds. Pseudomonas is often encountered in sea water, sediments, phytoplankton and zooplankton (Nair and Simidu, 1987). Photobacterium are usually found in marine environments, hence the requirement of sodium for growth. They may be free-living in the water, or found associated with intestinal contents of marine animals and with the light organs of fish (Baumann and Baumann, 1984).

The presence of Acinetobacter, Chromobacterium, Flexibacter, Moraxella and Vibrio was also remarkable. Members of the genus Acinetobacter are usually isolated in water. They are capable of degrading aromatic compounds and their metabolic versatility is comparable to that of the Pseudomonads (Abd-El-Haleen et al., 2002). Chromobacterium is ubiquitous in nature and found in waters from polar regions to the tropics. Flexibacter is abundant near the shore, on seaweeds and on decaying sea animals. Moraxella plays an important role in nitrogen cycling as well as Vibrio (Stolp, 1988). Vibrio occurs in saline aquatic environments, both free in the water and bound to animate and inanimate surfaces. These microorganisms are readily culturable from seawater, marine animals and seaweeds. Several studies on the role of Vibrio spp. in the marine environment have shown their importance in biodegradation, nutrient regeneration and biogeochemical cycling (Ducklow, 1983; Jorgensen, 1983; Colwell, 1994). In conclusion, in the Southern Adriatic Sea, the remarkable bacterial density and diversity observed throughout the year together with the high metabolic versatility of the identified genera shows the ability of the bacterial compartment to utilize the scarce trophic resources of such an oligotrophic ecosystem to their best: the different bacterial genera act synergically to accomplish complete degradation of the trophic substrates.

Finally, on the basis of the results obtained it is difficult to explain the reduction of bacterial diversity observed in May in Brindisi and Otranto and in November in S. M. di Leuca, as well as the increase observed in March in Otranto. It is well known that consumption or lysis by predators and viruses is considered a key control of the dynamics of bacterial communities. Probably such a phenomenon could justify the variations in bacterial diversity observed. Thus, further studies will be carried out to establish the eventual role of grazing and/or other factors, until now not well defined, on controlling bacterial distribution and diversity.

\section{REFERENCES}

Abd-El-Haleen, D., H. Noawad, E.A. Zaki and S.Zaki. - 2002. Molecular characterization of phenol-degrading bacteria isolated from different Egyptian ecosystems. Microb. Ecol., 43(2): $217-224$.

Azam, F. - 1998. Microbial control of oceanic carbon flux: the plot thickens. Science, 280: 694-696.

Azam, F., T. Fenchel, J.G. Gray, L.A. Meyer-Reil and F. Thingstad. - 1983. The ecological role of water-column microbes in the sea. Mar. Ecol. Prog. Ser., 10: 257-263.

Baumann, P. and L. Baumann. - 1984. Genus II. Photobacterium Beijerinck 1889. In: N.R. Kreig and J.G. Holt, (eds.), Bergey's Manual of Systematic Bacteriology, 1. Williams \& Wilkins, Baltimore.

Caroppo, C., A. Fiocca, P. Sammarco and G. Magazzù. - 1999. Seasonal variations of nutrients and phytoplankton in the coastal SW Adriatic Sea (1995-1997). Bot. Mar., 42: 389-400.

Camus, A.C., R.M. Durborow, W.G. Henstreet, R.L. Thune and J.P Hawke. - 1998. Aeromonas bacterial infections. Motile Aeromonad septicemia. SRAC Southern Regional Aquaculture Center, publ. $\mathrm{N}^{\circ} 478$.

Civitarese, G., M. Vetrano, A. Boldrin, D. Bregant, S. Rabitti and E. Souvermezoglou. - 1998. Biogeo-chemical fluxes through the Strait of Otranto (Eastern Mediterranean). Cont. shelf Res., 18: 773-789.

Colwell, R.R. - 1994. Vibrios in the marine and estuarine environment. In: 3th International Marine Biotechnology Conference, Tromsoe, Norway, 7-12 Aug.

DeLong, E.F., D.G. Franks and A.L. Alldredge. - 1993. Phylogenetic diversity of aggregate-attached vs. free-living marine bac- 
terial assemblages. Limnol. Oceanogr., 38: 924-934.

Ducklow, H.W. - 1983. Production and fate of bacteria in the oceans. Bio Sci., 33: 494-501.

Fonda Umani, S., P. Franco, E. Ghirardelli and A. Malej. - 1992. Outline of oceanography and the plankton of the Adriatic Sea. In: G. Colombo, I. Ferrari, V.U. Ceccherelli and R. Rossi (eds.), Marine eutrophication and population dynamics, pp. 347-365. Olsen \& Olsen, Fredesborg.

Franco, P., L. Jeftic, P. Malanotte Rizzoli, A. Michelato and M. Orlic. - 1982. Descriptive model of the Northern Adriatic Oceanol. Acta, 5: 379-389.

Franco, P. and A. Michelato. - 1992. Northern Adriatic Sea: oceanography of the basin proper of the western coastal zone. In: R.A. Vollenweider, R. Marchetti and R. Viviani (eds.), Marine coastal eutrophication, pp. 35-62. Elsevier, Amsterdam.

Fry, J.C. - 1987. Functional roles of major groups of bacteria associated with detritus. In: D.J.W. Moriarty and R.S.V. Pullin, (eds.), Detritus and Microbial Ecology in Aquaculture, pp. 83122. International Centre for Living Aquatic Resources Management, Manila, Philippines.

Fuhrman, J.A., K. McCallum and A.L. Davis. - 1993. Phylogenetic diversity of marine microbial communities from the Atlantic and Pacific oceans. Appl. Environ. Microbiol., 59: 1294-1302.

Fuhrman, J.A., S.H. Lee, Y. Masuchi., A.A. Davis and R.M. Wilcox. - 1994. Characterization of marine procaryotic communities via DNA and RNA. Microb. Ecol., 28: 133-145.

Gacic, M., V. Kovacevic, B. Manca, E. Papageorgiou, P.M. Poulain, P.M. Scarazzato and A. Vetrano. - 1996. Thermohaline properties and circulation in the Otranto Strait. Bull. Inst. Océanogr. Monaco CIESM Science Series, 2(17): 117-145.

Giovannoni, S.J., T.B. Britschgi, C.L. Moyer and K.G. Field. 1990. Genetic diversity in Sargasso Sea bacterioplankton. Nature, 345: 60-63.

Glöckner, F.O., B.M. Fucus and R. Amann. - 1999. Bacterioplankton compositions of Lakes and Oceans: a First comparison based on fluorescence in situ hybridization. Appl. Environ. Microbiol., 65 (8): 3721-3726.

Gonzáles, J.M. and Moran M.A. - 1997. Numerical dominance of a group of marine bacteria in the alpha-subclass of the class Proteobacteria in coastal seawater. Appl. Environ. Microbiol., 63: 4237-4242.

Hagström, A., Pinhassi J. and U. L. Zweifel - 2000. Biogeographical diversity among marine bacterioplankton. Aquat. Microb. Ecol., 21: 231-244.

Holt, J.G., N.R. Kreig, P.H.A. Sneath, J.T. Staley and S.T. Williams - 19949. Bergey's Manual of Determinative Bacteriology. Baltimore, Williams \& Wilkins.

Hugenholtz, P., B.M. Goebel and N.R. Pace. - 1998. Impact of culture-independent studies on the emerging phylogenetic view of bacterial diversity. J. Bacteriol., 180: 4765-4774.

Jørgensen, B.B. - 1983. Processes at the sediment-water interface. In: B. Bolin and R.B. Cook (eds.), The major biochemical cycles and their interactions, pp. 477-515. Wiley, New York.

Jürgens, K. and H. Güde. - 1990. Incorporation and release of phosphorus in planktonic bacteria and phagotrophic flagellates. Mar. Ecol. Prog. Ser., 59: 271-284.

Jürgens, K. and H. Güde. - 1994. The potential importance of grazing-resistant bacteria in planktonic systems. Mar. Ecol. Prog. Ser., 112: 169-188.

Kogure, K., U. Simidu and N. Taga. - 1979. A tentative direct microscopic method for counting living marine bacteria. Can. J. Microbiol., 25: 415-420.

Kuech, C.S. and K.Y. Chan. - 1985. Bacteria in bivalve shellfish with special references to the oyster. J. Appl. Bacteriol., 59: 41-47.

Martinez, J., D.C. Smith., G.F. Steward. and F. Azam. - 1996. Vari- ability in ectohydrolytic enzyme activities of pelagic marine bacteria and its significance for substrate processing in the sea. Aquat. Microb. Ecol., 10: 223-230.

Nair, S. and U. Simidu. - 1987. Distribution and significance of heterotrophic marine bacteria with antibacterial activity. Appl. Environ. Microb., 53: 2957-2962.

Orlic, M., M. Gracic and P. La Violette. - 1992. The currents and circulation of the Adriatic Sea. Oceanol., 15(2): 109-124.

Pace, M.L. and E. Funke. - 1991. Regulation of planktonic microbial comunities by nutrients and herbivors. Ecology, 72: 904-914.

Pinhassi, J., U.L Zweifel and A. Hagström. - 1997. Dominant marine bacterioplankton species found among colony-forming bacteria. Appl. Environ. Microbiol., 63: 3359-3366.

Pomeroy, L. R. - 1980. Microbial roles in aquatic food webs. In: R.R. Colwell and J. Foster, (eds.), Aquatic Microbial Ecology, pp. 85109. University of Maryland SeaGrant, College Park, Md.

Pomeroy, L.R. and W.J. Wiebe - 2001. Temperature and substrates as interactive limiting factors for marine heterotrophic bacteria. Aquat. Microb. Ecol., 23: 187-204.

Ramsing, N.B., H. Fossing, T.G. Ferdelman, F. Andersen and B. Thamdrup. - 1996. Distribution of bacterial populations in a stratified fjord (Mariager Fjord, Denmark) quantified by in situ hybrydization and related to chemical gradient in the water column. Appl. Environ. Microbiol., 62: 1391-1404.

Rehnstam, A.S, S. Bäckman, D.C. Smith, F. Azam and Å Hagström. - 1993. Blooms of sequence-specific culturable bacteria in the sea. FEMS Microbiol. Ecol., 102: 161-166.

Rheinheimer, G. and K. Gocke. - 1994. The use of bacteriological variables for the characterization of different water bodies. Int. Rev. Ges. Hydrobiol., 79: 605-619.

Rochelle, P.A., B.A. Cragg, J.C. Fry, R.J. Parkes and A.J. Weightman. - 1994. Effect of sample handling on estimation of bacterial diversity in marine sediments by $16 \mathrm{~S}$ rRNA gene sequence analysis. FEMS Micro. Ecol., 15: 215-226.

Russo, A. and A. Artegiani. - 1996. Adriatic Sea hydrography. Sci. Mar., 60: 33-43.

Sansers, R.W., D.A. Caron and U.G. Berninger. - 1992. Relationships between bacteria and heterotrophic nanoplankton in marine and fresh waters: an interecosystem comparison. Mar. Ecol. Prog. Ecol. Ser., 86: 1-14.

Shotts, E.B., J.L. Gaines, C. Martin and A.K. Prestwood. - 1972. Aeromonas induced deaths among fish and reptiles in an eutrophic inland lake. J. Am. Vet. Med. Assoc., 161: 603-707.

Sieburth, J. McN. - 1967. Seasonal selection of estuarine bacteria by water temperature. J. Exp. mar. Biol. Ecol., 1: 98-121.

Statsoft. 2001. Electronic statistics textbook. Statsoft, Tulsa, OK.

Stolp, H. - 1988. Microbial Ecology. Organisms, Habitats, Activities. Cambridge, Cambridge University Press.

Suttle, C.A., J.A. Fuhrman and D.G. Capone. - 1990. Rapid ammonium cycling and concentration dependant partitioning of ammonium and phosphate: implication for carbon transfer in planktonic communities. Limnol. Oceanogr., 35: 424-433.

Suzuki, M.T., M.S. Rappé, Z.W. Haimberger, H. Winfield, N. Adair, J. Ströbel and S.J. Giovannoni. - 1997. Bacterial diversity among small-subunit rRNA gene clones and cellular isolates from the same seawater sample. Appl. Environ. Microbiol., 63: 983-989.

Thingstad, T.F. and E. Sakshaug. - 1990. Control of phytoplankton growth in nutrient recycling ecosystems. Theory and terminology. Mar. Ecol. Prog. Ser., 63: 261-272.

Zaccone, R., G. Caruso, C. Calì and R. Scarfo - 1998. Primi dati sulla caratterizzazione microbiologica delle acque dell'Adriatico Settentrionale. In: Atti del $12^{\circ}$ Congresso dell'Associazione Italiana di Oceanografia e Limnologia, II (Piccazzo M., ed.), pp. 487-497. Isola di Vulcano 18-21 settembre 1996. 
